\section{ノ $-卜$}

J. Brew. Soc. Japan.

Vol. 90, No. 10, p. 800 802 (1995)

オリゴ糖を添加したキウイフルーツ

ジュースから製造したワインの特徴

高柳 勉 - 海野剛裕* - 山川祥秀 - 横塚弘毅 <山梨大学発醅化学研究施設, $*$ 日本食品化工(株) >

平成 6 年 11 月 14 日受理

Effects of Added Oligosaccharides on the

Characteristics of Wines Made from

Kiwifruit Juice

Tsutomu TAKAYANAGI, Takehiro UNNO*, YoshihideYAMAKAWA and Koki YokotsukA

(The Insitute of Enology and Viticulture, Yamanashi University, 1-13-1 Kitashin, Kofu, Yamanashi 400

* Nihon Shokuhin Kako Co., Ltd., 30 Tajima Fuji, Shizuoka 417)

Five kinds of wines were made from kiwifruit juices with various oligosaccharide mixtures containing maltotriose, maltotetraose, maltohexa-heptaose, cyclodextrin or gentiooligosaccharides as the main sugar, respectively. Dry and sweet wines without oligosaccharides were also made from the kiwifruit juices as the control. Little difference was observed in the $\mathrm{pH}$, total acidity, and total phenol of all the wines tested. The amounts of total oligosaccharides in all the wines fermented with oligosaccharides decreased during fermentation. The dry wine was characterized by a fruity taste, while the sweet wine had a good body from relatively strong sweetness. On the other hand, the wines fermented with oligosaccharides were appreciated as wines possessing mild body and sweetness.

Key words : キウイフルーツ・キウイフルーツワイン・ オリゴ糖一

\section{緒言}

ワイン中の主要な糖成分であるグルコースとフルクト 一スの示す甘味は, 酸味や苦味とのバランスをとる重要 な要素となっている ${ }^{1,2)}$ 。特にキウイフルーツワインにお いては, キウイフルーツ果汁からくる独特の苦味を打ら 消すために適度な甘味が不可欠である。従って, 適量の 糖を残して発酵を終了させるといらきわめて微妙な技術
が要求される。また，甘味を付加するために残存させた グルコースやフルクトースはワインボトル内で酵母や細 菌の繁殖を引き起こし， ワインの品質を低下させること もある。そこで, 発酔が終了した後も残存し，さらにボ トル内に残存しても酵母や細菌の繁殖を起こしにくい種 類の糖により甘味を付加することができれば， ワインの 品質管理がきわめて容易になると推測される。現在の日 本の酒税法では, 果実酒に添加する糖類はショ糖, ブド ウ糖, 果糖に限られており, その他の糖の添加は認めら れていない。しかし，ワインの品質の向上を目指した基 礎的研究として，このような非発酵性糖の添加実験は意 義があると考えられる。本研究では, 酵母によって資化 されにくい重合度 3 以上のオリゴ糖を発酵開始時に添加 してキウイフルーツワインを製造し，発酵後のキウイフ ルーツワインにオリゴ糖を残存させることを試みた。す なわち，各種のオリゴ糖を用いて，それらが発酵中にど のように変化するのか, さらに, 発醅後にどの程度の甘 味を付加できるかを検討した。

\section{実 験 方 法}

\section{1. キウイフルーツワインの製造}

山梨県八田村で 1992 年秋に収穫されたへイワード種 キウイフルーツから得た果汁に重合度 3 以上のオリゴ糖 （ただしゲンチオビオースを含む）の濃度が $2 \%$, 全糖濃 度が $20 \%$ になるように各種のオリゴ糖粉末およびショ 糖を添加した。オリゴ糖粉末として使用した日本食品 化工製の商品名フジオリゴ \#360（\#360），フジオリゴ

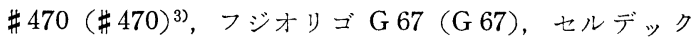

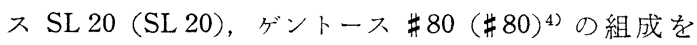
Table 1 に示した。比較のために製造した辛ロワインと 甘ロワインについてはオリゴ糖を添加せず，全糖量がそ れぞれ 18\%（辛口），20\%（甘口）になるようにショ糖 を加えた。補糖後の各果汁 $2 l$ に酒母を添加し, 発酵栓 をつけて $15^{\circ} \mathrm{C} て ゙ ~ 14$ 日間発酵させた。発酵試駼はそれ ぞれのオリゴ糖につき 2 回ずつ行い, 成分分析の結果は その平均值を示した。以後，オリゴ糖を添加して製造し たキウイフルーツワインを添加糖の種類から， \#360 ワ イン, \#470 ワイン, G 67 ワイン, SL 20 ワイン, \#80 ワインと呼ぶこととした。

\section{2. ワインの成分分析}

ワインのエタノール量はガスクロマトグラフィー分析 により求めた。カラムは Thermon-1000 (Sunpak-A 5 $\%, 3 \mathrm{~mm} \times 2 \mathrm{~m})$ を用い, $100^{\circ} \mathrm{C} \sim 160^{\circ} \mathrm{C}\left(6^{\circ} \mathrm{C} / \mathrm{min}\right)$ の 昇温条件下で分析した。総酸量は, 試料を $0.1 \mathrm{~N}$ 水酸 化ナトリウム水溶液で $\mathrm{pH} 8.2$ まで中和滴定し, 滴定量 からクェン酸の換算値として算出した。全フェノール量 
Table 1 Composition of oligosaccharide mixtures; \#360, \#470, G 67 , SL 20 and \#80 (weight \%)

\begin{tabular}{l|r|r|r|r|r}
\hline \hline & $\# 360$ & $\# 470$ & G 67 & SL 20 & $\# 80$ \\
\hline Fructose & - & - & - & - & 1.7 \\
Glucose & 4.0 & 2.0 & 4.4 & 2.2 & 5.8 \\
Maltose & 21.7 & 8.5 & 13.4 & 9.9 & - \\
Maltotriose & 60.0 & 11.0 & 7.9 & 12.2 & - \\
Maltotetraose & 7.6 & 72.0 & 7.6 & 5.6 & - \\
Maltopentaose & - & 1.0 & 7.6 & 10.4 & - \\
Maltohexa-heptaose & - & - & 40.0 & 12.6 & - \\
$\alpha$-Cyclodextrin & - & - & - & 5.6 & - \\
$\beta$-Cyclodextrin & - & - & - & 5.1 & - \\
$\gamma$-Cyclodextrin & - & - & - & 9.3 & - \\
Gentiobiose & - & - & - & - & 50.6 \\
Gentiotriose & - & - & - & - & 28.2 \\
Gentiotetraose & - & - & - & - & 13.7 \\
HMW* & 6.7 & 5.5 & 19.1 & 27.1 & - \\
\hline
\end{tabular}

* HMW, high molecular weight compound.

はSINGLETON と ROSSI の方法5) に従って測定し, 没 食子酸の換算值として算出した。全糖量はフェノールー 硫酸法 ${ }^{6)}$ によって测定し，グルコースの換算值として 算出した。オリゴ糖の定量は, HPLCにより行った。 HPLC のカラムは Aminex HPX-42 A $(7.8 \times 300$ mm, BIO-RAD), Ultron PS- $80 \mathrm{~N}(8 \times 500 \mathrm{~mm}$, 信和化工 $)$, Asahipak NH 2 P-50 (4. $6 \times 250$ mm, Shodex) を用い た。示差屈折計により溶出糖のピークを検出し，その面 積よりオリゴ糖量を算出した。

\section{3. 呈味試験}

味覚検査は, 利き酒試験に十分に経験のある研究者 6 人と 3 力月以上の経験のある学生 6 人（女性 3 人を含 む）の計 12 人で行った。辛ロワインの甘味を 2 と定め 甘味, 酸味, 苦味, 橴みの強さを 5 段階 ( 5 が最も強い) で評価した。総合評洒は各味のバランス, こく，後味な ぞを総合的にとら党， 5 段階（5が最も好ましい）で評 価した。

\section{実験結果および考察}

\section{1. キウイフルーツワインの成分分析}

オリゴ糖添加（\#360，\#470，G 67，SL 20，\#80）お よび非添加（甘口，辛ロ）のキウイフルーツワインの $\mathrm{pH}$, アルコール濃度, 総酸量, 総糖量, 総フェノール量 を Table 2 に示した。各キウイフルーツワインの $\mathrm{pH}$, 総酸量, 総フェノール量に大きな差は見られなかった。 しかし，総糖量は辛ロワインの $0.26 \%$ に対して甘ロワ インおよびオリゴ糖添加ワインは 1.17 1.86\% と高い 值を示した。

Table 3 に各キウイフルーツワインに残存している糖 の組成分析の結果を示した。ここで, 重合度 8 以上の分 離不可能な糖はすべて高分子糖 (HMW) とした。オリ ゴ糖を添加していない甘ロと辛ロのキウイフルーツワイ ンに技いてはグルュースに比べてフルクトースの残存量 が多いのに対して，オリゴ糖添加ワインはすべてグルコ 一スの方が多く残存していた。発酵終了後のキウイフル ーツワイン中の残存オリゴ糖の総量は, いずれも添加時 に比べて減少していた（Table 3)。個々のオリゴ糖にお いては \#360 ワインのマルトトリオースと\#470 ワイ ンのマルトテトラオースの減少が著しく， \#80 ワイン のゲンチオオリゴ糖の減少は小さかった。各オリゴ糖 は, 発酵中または発酵後に, 酵母または果汁由来の酵素 による加水分解やワインの低 $\mathrm{pH}$ 環境による化学的な 加水分解を受けているものと考光られる。オリゴ糖の加 水分解により生又出されるグルコースは, ワインボトル 内で酵母や細菌の繁殖を引き起こすことになり，この加 水分解を防ぐ，もしくは加水分解を受けにくいオリゴ糖 を選択することが今後の課題であると考学られる。SL 20 のシクロデキストリンの測定は， $\alpha-\mathrm{CD}$ が重合度 6 のオリゴ糖, $\beta-\mathrm{CD}$ がアルコール， $\gamma-\mathrm{CD}$ がグリセリン のピークとそれぞれ重なってしまらため, 正確な定量值 を得ることがでさなかった。

\section{2. 残存オリゴ糖と呈味試験結果の関係}

甘味, 酸味, 苦味, 渋みの強さを 5 段階で評価（ 5 が

Table 2 pHs and concentrations of alcohol, total acidity, total sugar, and total phenol in wines made from kiwifruit juices with or without oligosaccharides.

\begin{tabular}{l|c|c|c|c|c|c|c}
\hline & \multicolumn{2}{|c|}{ Without oligosaccharides } & \multicolumn{5}{|c}{ With oligosaccharides } \\
\cline { 2 - 8 } & Dry & Sweet & $\# 360$ & $\# 470$ & G 67 & SL 20 & $\# 80$ \\
\hline $\mathrm{pH}$ & 3.54 & 3.49 & 3.52 & 3.53 & 3.54 & 3.53 & 3.53 \\
Alcohol $(\%, \mathrm{v} / \mathrm{v})$ & 10.6 & 10.5 & 10.6 & 10.7 & 10.8 & 10.7 & 10.6 \\
Total acidity $^{\mathrm{a}}$ & 0.79 & 0.85 & 0.78 & 0.78 & 0.79 & 0.80 & 0.78 \\
Total sugar $^{\mathrm{b}}$ & 0.26 & 1.17 & 1.35 & 1.55 & 1.78 & 1.29 & 1.86 \\
Total phenol $^{\mathrm{c}}$ & 339 & 391 & 359 & 365 & 395 & 332 & 368 \\
\hline
\end{tabular}

${ }^{\mathrm{a}} \mathrm{g} / 100 \mathrm{ml}$, as citric acid ; ${ }^{\mathrm{b}} \mathrm{g} / 100 \mathrm{ml}$, as glucose ; ${ }^{\mathrm{c}} \mathrm{mg} / \mathrm{l}$, as gallic acid. 
高柳・海野・山川・横塚：オリゴ糖を添加したキウイフルーツジュースから製造したワインの特徵

Table 3 Concentrations of residual oligosaccharides in wines made from kiwifruit juices with or without oligosaccharides $(\mathrm{g} / 100 \mathrm{ml})$.

\begin{tabular}{|c|c|c|c|c|c|c|c|}
\hline \multirow[b]{3}{*}{ Fructose } & \multicolumn{2}{|c|}{ Without oligosaccharides } & \multicolumn{5}{|c|}{ With oligosaccharides } \\
\hline & \multirow{2}{*}{$\frac{\text { Dry }}{0.128(0)}$} & \multirow{2}{*}{$\frac{\text { Sweet }}{0.994(0)}$} & $\$ 360$ & $\# 470$ & G 67 & SL 20 & $\# 80$ \\
\hline & & & $0.125 \quad(0)$ & $0.240 \quad(0)$ & $0.135 \quad(0)$ & $0.183 \quad(0)$ & $0.156(0.036)$ \\
\hline Glucose & $0.025(0)$ & $0.084(0)$ & $0.643(0.108)$ & $0.670(0.045)$ & $0.820(0.107)$ & $0.421(0.050)$ & $0.195(0.125)$ \\
\hline Maltose & $0.008(0)$ & $0.003(0)$ & $0.122(0.584)$ & $0.136(0.190)$ & $0.132(0.326)$ & $0.102(0.225)$ & $0 \quad(0)$ \\
\hline Maltotriose & $0 \quad(0)$ & $0 \quad(0)$ & $0.175(1.616)$ & $0.183(0.246)$ & $0.207(0.192)$ & $0.157(0.278)$ & $(0)$ \\
\hline Maltotetraose & $(0)$ & $(0)$ & $0.051(0.205)$ & $0.051(1.610)$ & $0.063(0.185)$ & $0.037(0.127)$ & $(0)$ \\
\hline Maltopentaose & $(0)$ & $(0)$ & $0.016 \quad(0)$ & $0.023(0.022)$ & $0.051(0.185)$ & $0.030(0.237)$ & $(0)$ \\
\hline Maltohexa-heptaose & $0 \quad(0)$ & $0 \quad(0)$ & $(0)$ & $0 \quad(0)$ & $0.050(0.973)$ & $0.117(0.287)$ & $0 \quad(0)$ \\
\hline Gentiobiose & $0.008(0)$ & $0.003(0)$ & $(0)$ & $(0)$ & $0 \quad(0)$ & $0 \quad(0)$ & $0.801(1.094)$ \\
\hline Gentiotriose & $0 \quad(0)$ & $0 \quad(0)$ & $(0)$ & $(0)$ & $(0)$ & $(0)$ & $0.436(0.610)$ \\
\hline Gentiotetraose & $(0)$ & $(0)$ & $(0)$ & $(0)$ & $(0)$ & $(0)$ & $0.212(0.296)$ \\
\hline HMW & $0.095(0)$ & $0.086(0)$ & $0.214(0.180)$ & $0.245(0.123)$ & $0.050(0.465)$ & $0.243(0.617)$ & $0.059 \quad(0)$ \\
\hline Total & $0.264(0)$ & $1.170(0)$ & $1.346(2.693)$ & $1.548(2.236)$ & $1.784(2.433)$ & $1.290(1.821)$ & $1.859(2.161)$ \\
\hline
\end{tabular}

The values in parentheses show the concentrations of sugars added to kiwifruits juices before fermentation.

Table 4 Evaluation of wines made from kiwifruit juices with or without oligosaccharides.

\begin{tabular}{l|r|r|r|r|r|r|r}
\hline \hline & $\begin{array}{r}\text { Without } \\
\text { oligosaccha- } \\
\text { rides }\end{array}$ & \multicolumn{5}{|c}{ With oligosaccharides } \\
\cline { 2 - 6 } & Dry & Sweet & $\$ 360$ & $\$ 470$ & G 67 & SL 20 & $\$ 80$ \\
\hline Sweetness & 2.0 & 3.7 & 2.7 & 2.5 & 2.8 & 2.4 & 2.5 \\
Sourness & 3.7 & 2.9 & 3.4 & 3.0 & 3.1 & 3.3 & 3.1 \\
Bitterness & 2.6 & 2.0 & 2.7 & 2.7 & 2.3 & 2.9 & 2.7 \\
Astringency & 2.3 & 2.2 & 2.0 & 2.1 & 1.9 & 2.1 & 2.1 \\
Overall & 2.8 & 3.3 & 2.8 & 2.6 & 2.7 & 2.4 & 2.5 \\
$\quad$ quality & 2.8 & & & & & &
\end{tabular}

最も強い）した結果と総合評価（ 5 が最も好ましい）を Tabe 4 に示した。辛ロワインの甘味を 2.0 (基準値) とすると, フルクトース含量の高い甘ロワインの甘味は 当然のことながら， 3.7 と大きな值を示している。オリ ゴ糖添加ワインはいずれも総糖量が甘ロワインと同程度 $(1.29 \sim 1.86 \mathrm{~g} / 100 \mathrm{ml})$ 存在するにもかかわらず甘味は $2.4 \sim 2.8$ と甘ロワインに比べて低い值を示した。辛口 ワインがフルーティーさ，甘ロワインが比較的強い甘味 からくるこくにより評価されているのに対して，オリゴ 糖添加ワインはマイルドな甘味とこくが評価された。特 に\#360 ワインはこくがあり，まとまりが良いとして， 総合評価も 2.8 と他のオリゴ糖添加ワインよりも高い 評価を得ている。しかし，一部のオリゴ糖添加ワインに おいて後味の悪さ，苦味を感じるパネラーもいた。 \#80 ワインは残存しているゲンチオオリゴ糖の独特の苦味が 感じられ，辛ロワインを好をパネラーは高い評価を与え たが，甘口を好さパネラーの評価は低かった。

\section{要約}

オリゴ糖添加および非添加のキウイフルーツから製造
した各ワインの $\mathrm{pH}$, 総酸量, 総フェノール量に大きな 差は見られなかった。オリゴ糖添加ワイン中の残存糖は フラクトースに比ベてグルコースが多く，オリゴ糖の総 量はいずれも添加時に比べて減少していた。個々のオリ ゴ糖では，マルトトリオース脑びマルナテトラオース の減少が著しく，ゲンチオオリゴ糖の減少が小さかった オリゴ糖添加ワインはいずれも総糖量が甘ロ（オリゴ 糖非添加）と同程度 $(1.29 \sim 1.86 \mathrm{~g} / 100 \mathrm{ml})$ 検出される にもかかわらず，甘味は甘口に比べて低い值を示した。 オリゴ糖添加ワインはマイルドな甘味とこくが評価され た。特に，マルトトリオースを主体とするオリゴ糖粉末 を添加して製造したワインはこくがあり，まとまりが良 いとして，総合評価も高かった。

終わりに，醸造試験を行うにあたりご協力いただきま した八田村役場ならびにフジッコワイナリー（株）の皆 さまそして本研究をまとめるに際して貴重な御助言を いただきました山梨県工業振興課技術指導監の渡辺正平 氏に感謝いたします。

\section{文献}

1) C. Buteau, C. L. Duitschaever and G. C. Ashton: Am. J. Enol. Vitic., 30, 139 (1979)

2) C. L. Duitschaever, C. Buteau and G. C. Ashton: Am. J. Enol. Vitic., 31, 337 (1980)

3) M. OKADA and T. NAKAKUKI : Starch Hydrolysis Products. p. 335, VCH Publishers, N. Y. (1992)

4）海野剛裕, 中久喜輝夫, 貝沼征四郎, 形浦宏一, 岡田嚴太郎：応用糖質科学, 41, 317 (1994)

5) V.L. Singleton and J. A. Rossi, J. R.: $A m$. J. Enol. Vitic., 16, 144 (1965)

6) M. Dubois., K. A. Gilles, J. K. Hamilton, P. A. Rebers and F. Smoth : Anal. Chem., 28, 350 (1956) 